IRSH 47 (2002), pp. $65-85$ DOI: I0.I0I7/S0020859002000780

(C) 2002 Internationaal Instituut voor Sociale Geschiedenis

\title{
Whose Left? Working-Class Political Allegiances in Post-industrial Britain*
}

\author{
DARRENG. LILLEKER
}

A romanticized view of class alignment in Britain exists that has been attacked and defended equally in academic works over the last twenty years. ${ }^{\mathrm{I}}$ Historically, the Labour Party was seen as the defender of workingclass interests, though critics within the party and the British socialist movement have often questioned this notion. ${ }^{2}$ Such questions have appeared more pertinent with the diminution of the working class due to the de-industrialization of the British economy. In I983 Andrew Gamble noted that: "The greatest threat to this underlying strength of the British labour movement are the twin trends of declining manufacturing output and rising unemployment". ${ }^{3} \mathrm{He}$ argued that it was the failure of the Labour Party to arrest these trends and "translate the overwhelming objective strength $[\ldots]$ into organizational strength and political leadership" ${ }^{4}$ which had led to the dealignment of the working class away from Labour.

Clearly, however, the Labour Party has never enjoyed the support of the working class in totality and the politics of the party have, on occasions, led sections of the working class to abandon the party.5 The fact that the British working class has historically had a weak partisan attachment to the Labour Party had been highlighted as evidence of dealignment long before the I980s. Studies of partisanship decline have illustrated that workingclass dealignment has been a long-standing feature of British politics. Franklin argues that this began in the mid-1960s, ${ }^{6}$ a thesis reinforced by

\footnotetext{
* The author would like to thank Janet Foxcroft, Ros Pinder, and Teresa Thorn for their invaluable and unpaid assistance with conducting the pilot studies, and Steve Ludlam and James Stanyer for their helpful comments on an earlier draft.

I. For an outline of the debate on dealignment see G. Evans, "Class Voting: from Premature Obituary to Reasoned Appraisal", in idem (ed.), The End of Class Politics? Class Voting in Comparative Context (Oxford, 1999), pp. I-2.

2. For example see R. Miliband, Parliamentary Socialism: A Study in the Politics of Labour (London, 1972).

3. A. Gamble, "The Impact of the SDP", in H. Drucker (ed.), Developments in British Politics (London, I983), p. 299.

4. Ibid., p. 300.

5. J.E. Cronin, Labour and Society in Britain $1918-1979$ (London, 1984).

6. M.N. Franklin, "Is Class Still the Basis of British Politics?", Strathclyde Papers on Government and Politics, 2 (1983), pp. I-3; M.N. Franklin and A. Mughan, "The Decline of Class Voting in Britain: Problems of Analysis and Interpretation", American Political Science Review, 72 (1978), pp. 523-534.
} 
analyses based on the Alford indexes of class voting which show a steady decline after 1966, though some highlight that dealignment only became worthy of attention during the I980s.7 Gallie highlighted the link between dealignment and de-industrialization by discussing the decline of class in terms of the diminution of class-consciousness. ${ }^{8}$ In arguing that the traditional sources of grievance - salaries and working conditions - are no longer as serious to the majority of working-class employees, he hypothesized that conflict was becoming avoidable through "social integration" in the modern workplace. This minimized the social distance between management and workforce, allowed equal participation in decision-making, and made trade-union activists irrelevant in securing benefits for the workforce.9 Gallie's conclusion was that the British working class, particularly those in the post-industrial economy, act upon personal, rather than class-conscious motivations and no longer need representation by a party whose agenda is built upon the interests of a nonexistent stereotypical social class. Such arguments allude to the inference that, as the working class became more affluent, parties claiming to represent the working class have had to adopt policies with a broader appeal. However, Goldthorpe et al., in their seminal study of the "affluent worker" (I 969), did not propose that social divisions along class lines were in anyway being eroded. The authors observed that: "in the case of manual workers, a shift away from a community-oriented form of social life towards recognition of the conjugal family and its fortunes as concerns of overriding importance". ${ }^{\circ} \circ$ This indicates that, while still working-class, the interests of the family and personal wealth had begun, as early as the I960s, to inform voting behaviour.

The perception that class and class-consciousness were becoming increasingly irrelevant in political terms led Tony Wright to argue that the term class needed to be exchanged for "people". In his highly plausible account of the role of the working class in British politics, he recognized that, more often than not, the working class has failed "to perform its necessary revolutionary or historic role". This, he argues, should not signal the end of socialism but prompt socialists to search for a new constituency consisting of "those people in search of a more rational, secure and human way of ordering society". ${ }^{\text {II }}$ While this observation is prescient in terms of the post-I995 adjustment of Britain's "New" Labour party programme, it is certainly not a new phenomenon. As the British working class has

7. D. Robertson, Class and the British Electorate (Oxford, 1984), p. 20.

8. D. Gallie, In Search of a New Working Class: Automation and Social Integration within Capitalist Enterprise (Cambridge, 1978), p. 295.

9. Ibid., pp. 300, 308-309.

Io. J.H. Goldthorpe, D. Lockwood, F. Bechhofer, and J. Platt, The Affluent Worker in the Class Structure (London, I969), p. I63.

I I. T. Wright, Socialisms: Old and New (London, 1996), p. I04. 
historically refused to adopt the role Marxist theorists ascribed to it, it would seem that the working class has been placed on a pedestal undeservedly. Within Britain, in the writings of key theorists and political actors, as Kreiger explains: "a few core male manufacturing industries were allowed to stand symbolically for the whole of a segmented and highly sexsegregated labor force". ${ }^{\mathrm{I} 2}$ These industries became symbolic because they allowed "an understanding of a shared lot" " 3 which encouraged collectivist behaviour. ${ }^{14}$ This gave an impression of unity, cohesion, and collectivity but was actually limited to certain sectors of the economy, specific modes of production, and centred on key trade unions. These factors are largely no longer a feature of the British political scene.

The above brief discussion provides an introduction to the debate surrounding the influence of class-consciousness upon voting behaviour in an historical perspective. This article seeks to revisit and question some of the assumptions of class alignment before discussing the effects of deindustrialization on the position and influence of the working class in Britain at the turn of the twenty-first century. The study will be structured in the following way. Firstly, an overview of the traditional alignment of the working class; secondly, an introduction to Britain as a post-industrial economy, which will necessitate us rethinking various assumptions regarding the nature and composition of the working class. The third section of the paper will attempt to define the socioeconomic profile of the modern British working class and, once a broad definition of the postindustrial working class has been established, the final section can then focus upon the voting behaviour of those who can be classified as workingclass. The main aims of this article is to examine whether class can be realistically described as a factor which influences voting in Britain and, if we reach a negative conclusion, develop some sense of what factors do determine voting patterns.

\section{THE WORKING CLASS IN BRITAIN: PARTISANSHIP VERSUS SELF-INTEREST}

A traditional, and arguably a rather utopian, view of partisanship would be that the British working class coalesced behind the Labour Party as the parliamentary force which represented their interests. ${ }^{15}$ This is highly

I 2. J. Kreiger, British Politics in the Global Age: Can Social Democracy Survive? (Oxford, 1999), p. 42.

13. A. Przeworski, Capitalism and Social Democracy (Cambridge, 1985), p. 100.

I4. On this point see E.O. Wright, Classes (London, I985), p. Iо.

I 5 . This was certainly the view of the key theorists of the party, such as Sydney Webb, Harold Laski, and G.D.H. Cole, and was supported by many on the left of the party who argued for a more "socialist" agenda. Such a stance would be exemplified in the works of Tony Benn and Konni Zilliacus. 
questionable. While the Labour Party did emerge "from the bowels of the trade union movement" it was hardly an easy delivery. Only just over 50 per cent of delegates voted to establish the Labour Representation Committee at the 1899 Trade Union Congress ${ }^{16}$ and it took a further ten years for the party to attract the majority of large trade unions away from the Liberal Party. ${ }^{17}$ It remained even more difficult for the Labour Party to attract a core electorate. As Ralph Miliband argued: "most Labour supporters were not socialists, only anti-Conservatives. And, for those who did not want to vote Conservative, there was no serious alternative to the Labour Party, just as there was no longer any serious alternative to the Conservative Party for those who would not vote Labour". ${ }^{18}$ While 1945 represented the highpoint for Labour support, it also marked the watershed. Labour's victory was underpinned by a cross-class consensus of public opinion that demanded better public services and substantial welfare reforms and believed Labour was the party to deliver; class identity arguably held little significance. Therefore we can offer the perspective of the working class as a highly amorphous group, the interests of which were often divided between group identity and personal economic interests.

This hypothesis is substantiated by the phenomena of working-class conservatism. Surveys show that 25 per cent of the core Conservative vote $^{19}$ comes from households within the lowest income bracket and, moreover, 22 per cent of Conservative Party voters count themselves as working-class. However, these are not, perhaps, those who are traditionally seen as possessing a working-class consciousness. A survey conducted in 1994 found that the majority of this cohort own their own property, are aspirant, oppose the closed-shop trade-union policy, have no significant view on privatization and also have strong nationalistic tendencies. They are ambivalent to the idea of the strong "nanny" state and desire the ability to accumulate wealth unhindered by high "tax and spend" governments. ${ }^{20}$ This is a significant, and arguably expanding, group whose members are currently seen as "middle Englanders" and who lack a strong partisan identity. The first evidence that this cohort existed was presented by Goldthorpe et al. in 1969 who argued that there was

I6. A. Thorpe, A History of the British Labour Party (Basingstoke, 1997), p. 5.

17. A major advance was the affiliation of the Miner's Federation of Great Britain in I 909, giving the party 88 per cent of the members of the Trade Union Congress (TUC). See Thorpe, $A$ History, p. 23.

I8. Miliband, Parliamentary Socialism, p. i I9.

19. This figure denotes those who are loyal Conservative voters rather than working-class voters who may vote Conservative in reaction to the Labour Party failing to deliver on promises. The majority of surveys and studies give the figure as 25 per cent, though some argue that the average is as high as 30 or even 33 per cent.

20. P. Whiteley, P. Seyd, and J. Richardson, True Blues: The Politics of Conservative Party Membership (Oxford, 1994). 
[...] a considerable shift of working-class sentiment away from Labour [...] [and] likely defectors are individuals who had looked to the advantages which a Labour Government could bring in terms of prices, full employment, social benefits and now feel cheated mainly because it is these direct personal advantages that have been withheld. ${ }^{2 \mathrm{I}}$

Twelve years prior to publication of Goldthorpe et al.'s study the Labour leaders had also recognized the need to appeal to a broad range of individualist interests. Hugh Gaitskell, Party Leader 1955-1963, told the I957 Labour Party annual conference that a further programme of industrial nationalization had little appeal among "the so-called marginal voters, ordinary decent people who do not probably think a great deal about politics". He therefore argued that it would be a grave error for the party to develop a policy based purely on ideological socialist premises, particularly one that: "in our hearts we did not believe we could carry out [...] which in our hearts we believed the electorate would reject". ${ }^{22}$ Gaitskell firmly believed that the majority of the working class were not socialists and so would reject Labour if the party offered a socialistic manifesto. This led Butler and Rose to conclude that all Labour intrinsically asked of the electorate was to adopt the view that the party "could administer the mixed economy welfare state better than the Conservatives". ${ }^{23}$ The firm proof that the working class would reject a socialist Labour programme was provided at the 1983 General Election, but we can also point to I970, I979 and the period I95I-1959 to reinforce the point that the working class often did reject the politics of the Labour Party. In 1983 studies show that over one-third of those who were classified as working-class by the Alford index, 34 per cent and 36 per cent respectively, voted for the Conservative Party and $2 \mathrm{I}$ per cent indicated that this was a shift in their voting behaviour. Some analysts argue that this was more in reaction to Labour's leftward trajectory than evidence of a broader pattern of dealignment, and highlight 1983 as providing the necessary proof. Heath is quoted as arguing that: "in 1983 Labour fared badly in all classes alike. [But] It remained relatively stronger in the working class than in the middle class - in other words it remained a class party, but in 1983 it was an unsuccessful class party." ${ }^{24}$ Class, despite being described as irrelevant, continues to hold some significance. In 1993 Marshall found that only 6 per cent of respondents refused to assign themselves to a social class, therefore highlighting that some form of class-consciousness existed. However, his survey also discovered that

21. Goldthorpe et al., The Affluent Worker, p. I91; see also M. Abrams, "The Lost Labour Voter", Socialist Commentary, (February 1969), pp. 4-5.

22. Labour Party Annual Conference Report (1957), p. I55.

23. D.E. Butler and R. Rose, The British General Election of 1959 (London, 1960), p. 17.

24. G. Marshall et al., Social Class in Modern Britain (London, 1993), p. 230. 
employment sector, housing tenure, and level of benefit dependency also featured as variables which influenced voting behaviour. ${ }^{25}$ Evidence presented by more recent polls on voting behaviour suggest that traditional Labour voters are no longer loyalists at electoral polls but have become disillusioned and so voluntarily disenfranchized.

This process of disillusionment with Labour was first noted by Barry Hindess in $197 \mathrm{I}$. He highlighted that:

$[\ldots]$ the determination of local policy is now very largely in the hands of [...] [the] middle-class. [...] [D]ebate is able to centre more round questions of means and less around those of ends, and [...] for local or national government action to be judged in terms of its promise rather than its practical consequences. [...] The apparent growth of consensus is [...] directly related to the political isolation of a fairly substantial section of the population. ${ }^{26}$

Panitch reinforced these claims, highlighting that Labour had attempted "to develop a policy of national and party interest which will be acceptable to a broad range of sectoral organizations". ${ }^{27}$ The concern is which sectors will be prioritized and which will be excluded in the modern British political arena.

It was the middle class that New Labour specifically targeted when adopting a market-oriented approach to electoral campaigning. ${ }^{28}$ Philip Gould, senior adviser to the Labour Party campaigns and communications strategists since 1986, described these people as: "Not disadvantaged, not privileged, not quite working-class, not really middle-class - they don't even have a name." 29 Drawing on the Democrats' campaign in the United States, Gould argued the party "need[ed] to reassert their claim to represent the majority of working [people]. The working middle class needs to figure at least as centrally in the party's identity as the traditional blue-collar [manual labourer] imagery". ${ }^{\circ}$ This does not mean, however, that Labour has abandoned, or indeed lost, what is known as "heartland" support. In the $200 \mathrm{I}$ General Election, key constituencies showed a substantial support for Labour, despite also evidencing voter apathy by a reduced turnout. Across the Barnsley wards, the former centre of the Yorkshire mining community and a traditional stronghold of Labour supporters, Labour gained above 60 per cent of the vote. This was mirrored in almost all the industrial heartland constituencies, the Conservative vote often struggled to top 20 per cent and the only gains

25. Ibid., pp. 249-253.

26. B. Hindess, The Decline of Working-Class Politics (London, I971), pp. I43-I45.

27. L. Panitch, Working-Class Politics in Crisis: Essays on Labour and the State (London, 1986), p. 57.

28. See J. Lees-Marshment, Political Marketing and British Political Parties: The Party's Just Begun (Manchester, 200I), pp. 181-210.

29. P. Gould, The Unfinished Revolution (London, 1998), p. I7.

30. Ibid., p. I73. 
in terms of percentage of votes went to the Liberal Democrats, Labour's main opposition on the centre-left.

The Labour heartland was as easily definable in the 1983 General Election, the low point for Labour voting. Those constituencies which experienced the greatest difficulties under Prime Minister Margaret Thatcher's neoliberal economic reforms were staunch Labour voters. These included the South Yorkshire and Nottinghamshire mining communities, Tyneside, Teeside, Liverpool, the West Midlands, Manchester, and parts of London, and can be classified as the traditional centres of the manufacturing and extraction industries. Beyond these areas Labour struggled to hold seats that were previously regarded as "safe". This led many electoral analysts to argue that class dealignment was well underway. ${ }^{31}$ However, this was not simply a case of the working class moving away from social-democratic parties; in Britain they moved away from Labour. Labour's failure to arrest economic depression I976- I 979 and the leftward drift 1980-1983 led the party to lose the support of all but those voters who would not under any circumstances vote Conservative. Crewe's surveys found that the reason for this was that the majority of working-class opinion "coincided more closely with Conservative policystances".32 Crewe found a "spectacular decline in support for the collectivist trinity of public ownership, trade union power and social welfare".33 Therefore the working-class Conservative voting cohort increased as a result of the Labour Party's failed economic policy and subsequent leftward shift. These voluntarily dealigned or realigned voters were the people who Gould would encourage the party to reorient itself towards at the 1997 General Election. However, should the realignment that occurred in 1983 be accepted as evidence of class dealignment?

Saunders argued that 1983 represented a rejection of the values of the Labour Party and evidenced the emergence of a "culture of consumption" among a substantial section of the working class. This led him to conclude that: "[w]e are moving towards a dominant mode of consumption in which the majority will satisfy most of its consumption requirements through private purchase". Here Saunders was not only discussing the family car, videorecorder, or personal stereo, but also essential welfare services. He also hypothesized that an underclass would emerge: "cast adrift on the waterlogged raft of the welfare state". ${ }^{44}$ This gives the impression that Saunders predicted a society of "haves and havenots" would emerge and

3. I. Crewe, “The Labour Party and the Electorate", in D. Kavanagh, The Politics of the Labour Party (Oxford, 1982), pp. 20, 23. See also I. Crewe, "The Electorate: Partisan Dealignment Ten Years On”, West European Politics, 7 (1984), pp. 19-28.

32. E. Shaw, The Labour Party Since 1979: Crisis and Transformation (London, 1994), p. 23.

33. Crewe, "The Labour Party", p. 37.

34. P. Saunders, Social Theory and the Urban Question (New York, 1986), p. 3 I 8. 
that the majority of the former would lack any party identification. Kreiger developed this point thus:

The political-electoral implications of the politics of consumption are $[\ldots]$ as much behavioural as structural, the use to which they can be put in party competition depend upon the policy options that drive them, the vision of politics that frames them, and the contemporary popularity of the party and the leader who enunciate them. 35

Thus, as was discussed twenty years previously in the affluent-worker thesis, politics has become contextualized within the personal circumstances of the voter. Kreiger used the selling of council houses to emphasize his argument. The council estates, usually situated within labour-intensive industrial urban centres, were the core of Labour's heartland support. However, with the transition from tenant to homeowner, new "anticollectivist" concerns became prominent. The newly empowered homeowners rejected the notion of community and class interest and embraced Thatcherite individualism. This process of gradual dealignment, due to the shifting values of working-class voters, is argued to have started in the late I960s, as consumerism first became a feature of British society, and caused an erosion of Labour's electoral support. ${ }^{36}$ Many argued that this was evidenced most acutely in 1983 , and claim that it was only when Labour rejected traditional socialist policies that the party was able to reverse the trend.

Clearly a large section of the working class did reject Labour in 1983 , some of whom would not return until 1997, suggesting substantial dealignment. Furthermore the use of marketing techniques, attempting to inject the "general will" into Labour party policy 1995-I 997 through a prolonged market-research exercise, gives the impression that Labour lacked a core constituency. However, what overrides these arguments is the notion of competence. Labour, post-1997, has been able to command a large majority of the electorate while the Conservatives appear to have lost a large majority of both their "heartland" voters and the non-aligned electorate. Labour is seen as more capable and, therefore, has currently established itself as the natural party of government. This argument is reinforced by the fact that a large percentage of the modern electorate is either apathetic to all major parties, or at least do not identify with either the Conservatives or Labour, but vote on the strength of a parties image of competence. This is linked to a popularized view that the parties are "too

35. J. Kreiger, "Class, Consumption, and Collectivism: Perspectives on the Labour Party and Electoral Competition in Britain”, in F.F. Piven (ed.), Labour Parties in Post-industrial Societies (Cambridge, I991), pp. 47-70, especially p. 58.

36. I. Crewe, "Labour Force Changes, Working-Class Decline, and the Labour Vote: Social and Electoral Trends in Postwar Britain”, in Piven, Labour Parties, pp. 20-46, especially pp. 2 I-24. 
similar", "lack a clear identity" and, to some, "are not ideologically driven". ${ }^{37}$ However, it could also be argued that the working class, due particularly to de-industrialization, has declined in numbers to such an extent that it is now a negligible political force. Therefore all the parties are fighting for the support of an apolitical, middle-England cohort who are motivated purely by economic concerns and who have no ideological affinities.

\section{DE-INDUSTRIALIZATION: THE REORIENTATION OF THE BRITISH WORKER}

The working class is traditionally seen as the manual worker, centred within the manufacture or extraction industries. This is clearly no longer the case. As Graham and Spence highlighted, "[ $\mathrm{t}]$ he decline of industrial manufacturing and the concurrent growth in service-sector-oriented activity have been features of change in most advanced urban economies over the last two decades". ${ }^{8}$ Crewe observed this process in I99I and described the ramifications as "a smaller labour force, a smaller working class, a contraction of trade unionism, mass unemployment, and a much larger 'peripheral' workforce of part-time and temporary workers". 39 Social trends data reinforce these claims. In I97I, 54.7 per cent of the total workforce ${ }^{40}$ was classed as manual workers, by I99I this had fallen to 37.7 per cent..$^{\mathrm{I}}$ More indicative of the level of reorientation is the fact that in I995 only 17.6 per cent of the total workforce worked within the manufacturing industry, a figure which included those employed in specialized manufacturing such as pharmaceuticals. Additionally only I per cent worked in energy-supply industries, which includes extraction, and 3.9 per cent in the construction sector. This means that the traditional working class industries employed an average of only 22 per cent of the workforce..$^{2}$ So where do the British people work in the post-industrial economy? Twenty-four per cent work in the distribution, and hotels and

37. Comments made by those interviewed who responded that they did not intend to vote, or had not voted, in 200I. See The Guardian (8 June 200I) and The Daily Telegraph (8 June 200I). These responses were also recorded by local newspaper journalists: see, for example, Leicester Mercury (5 June 200I), p. Iо; ibid., (6 June 200I), pp. 4-5. While those interviewed obviously cannot reflect a representative sample of all nonvoters, they are indicative of the opinions held of the major parties at that time.

38. D. Graham and N. Spence, "Contemporary Deindustrialisation and Tertiarisation in the London Economy”, Urban Studies, 32 (I995), p. 885.

39. Crewe, "Labour Force Changes", p. 25.

40. This includes full-time and part-time workers, male and female productive units and covers every industry.

4I. Census records, Social Trends Dataset: ST30A2; Percentage of Manual Workers I9I I-I 99I. 42. Figures use data for 1995, 1996, and 1997, See Office for National Statistics, Annual Employment Survey Revised: Employment Analysis 1995-1997, Dataset AES95-97. 
restaurants categories, within which are included the retail and wholesale trade and the majority of leisure-related services: hotel, restaurant, and licensed bar staff particularly. Eighteen per cent work within the finance sector (43 per cent of this cohort are classed as skilled), though the remaining 57 per cent come under the category of other business-related activities. This category mainly includes clerical staff attached to the finance industry, in particular call-centre workers, the sector referred to by Third-Way intellectual Charles Leadbeater as: "the factories of the modern service economy". 43 The other large category is public administration, employing 25 per cent of the workforce: the majority of these employees are skilled in educative or social-work skills, but 22 per cent are classified as routine administrative staff.

These dramatic changes in the structure of the British economy occurred between 1970 and I980, and had serious political repercussions. The overall levels of employment had dropped steadily from i966 due to a contraction in manufacturing, the service industry was able to offer some relief to the employed but became the employer for a greater number of women than men. ${ }^{44}$ The decline of manual industry caused a general unease among employees in the heavy industries - fuel extraction and steel manufacture - particularly as working conditions and real-wage levels began to decline. In many industries antagonism between management and workers was characterized as a battle over shopfloor control. The working classes sought guarantees over tenure and wage increases above the level of inflation, but underpinned these with demands for workplace democracy. Those manual workers who felt their personal circumstances were most under threat equally recognized that the Labour party was both illequipped and ill-prepared to arrest social change in favour of the working class. Thus the increase of militancy, in the workplace and within the Labour party, was an attempt to gain true working-class power. Those workers who felt that they could adapt to a service economy rejected the politics of the Left and embraced the individualism of Conservative politics. These members of the working class, and their descendants, are the modern era's floating, or nonaligned, voters. Their political allegiances are no longer defined by their employment and though, as we shall see, they face an even more uncertain future as a member of the fragmented working class in an unstable service economy they are, as Cronin observed: "more self-confident and assertive, less inclined to accept the dismally low standards of the past and quite intolerant towards the pretensions and authority of employers, trade union officials and the state". 45

43. C. Leadbeater, Living on Thin Air (London, 2000), p. 6 I.

44. Cronin, Labour and Society, p. I95.

45. Ibid., p. 208. 
Social-trends data reinforce this picture of the post-industrial British economy. They indicate that there has been a significant shift away from industrial and manual labour and towards the service sector. Traditionally these "white-collar" or "blue-stocking" occupations were seen as well paid and semiskilled or skilled. Studying data on age, gender, wages and education, we can see this is no longer the case. In terms of age and gender there is little significant difference, apart from the fact that young males, sixteen to thirty years of age, and females, thirty to forty years of age, are preponderant within the "other business-related category" with young females aged eighteen to twenty-five forming a further sizeable cohort. Males within the administration and service sectors earn on average

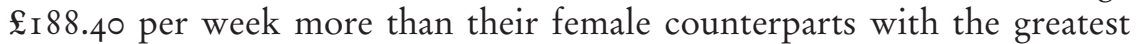
disparity - $£_{26} 6$ I.20 - being in the London area. ${ }^{46}$ The average wage for 30 per cent of all service sector employees is between $£_{4}$ and $£ 6$ per hour with a further I 2 per cent earning the minimum wage. Only 37 per cent of service sector employees earn over $£ 8$ per hour. ${ }^{47}$ Around 20 per cent of the total employees are part-time, 65 per cent of which are female..$^{8}$ Within the latter cohort we find that wages are on average lower and more likely to be set at the minimum level. Furthermore 52 per cent of service sector employees have no qualifications above GCSE and I0.3 per cent have no qualifications at all. ${ }^{49}$

This indicates that the service sector employs a large amount of women, often those who have devoted a significant period of their early adult life to childbearing. They have a low level of educational qualifications and, therefore have low earning capacity and lack basic employment-related skills such as computer literacy. These would have traditionally been the staple employees of the manufacturing industry. Using various social stratification measures we could define these people as working-class, though it is debatable whether they would classify themselves as such. Without carrying out a survey of all call centre operatives, low-grade administrators and other "customer-care" employees, it is impossible to gain a complete picture of the social and economic circumstances of this cohort, though a limited survey did produce some indications.

A pilot study of employees in three call centres, based in Leicester, Preston and Wakefield, $5^{\circ}$ revealed that 50 per cent do classify themselves as

46. Office for National Statistics, Average Weekly Earnings: by Industry and Gender, Regional Trends Dataset RT355ir.

47. Office for National Statistics, Distribution of Hourly Earnings: by Industry, (Spring 2000), New Earnings Survey Chart 5.10.

48. Office for National Statistics, Labour Force Survey, Regional Trends Dataset RT 35503.

49. Department of Education and Skills, Regional Trends Dataset RT354I3.

50. Simple questionnaires were designed and passed to a random sample of call-centre employees asking how they saw themselves, why they were in this occupation, and how long they planned to remain doing this type of work. 
working-class. And that 47 per cent do so on the strength of their background or, in the case of 16 per cent of respondents all of whom are female, based on the occupation of their partners. Only 24 per cent made a clear link between their occupation and their social class. ${ }^{\text {II }}$ Despite describing their jobs as "repetitive", "boring" and "scripted" - the latter in terms of the phrasing they use when discussing customer's complaints - 37 per cent see themselves as skilled and a further 47 per cent described themselves as semiskilled. All said they had some qualifications, but few of these thought they were relevant to their current occupation. The majority, 63 per cent, stated they were working because their household needed the money; only 44 per cent responded that they were working for personal spending money. But do their circumstances influence their voting? Forty-three per cent argued that they voted because of class partisanship, arguing that the Labour Party represented "people like them" or talked of "traditional", "family", or "community" ties to the party. The remainder, 57 per cent, all claimed they voted on the strength of "who would do best", "competence" or "who came across as a good leader".

A further indicator that also tells us much about the modern British economy is the lack of job security and increased mobility. This means that 75 per cent of the call-centre employees argued their job was "short-term" and a "stepping stone to a better job". Only is per cent saw themselves as restricted to call-centre work, while io per cent, obviously all females, were working in order to afford time off to have a baby. These indications are reinforced by nationwide studies. A survey of employment duration published in spring 2000 found that only io per cent of women between 20 and 49 years of age remain in a single post for more than one year. Fiftytwo per cent of women aged I 6 to I9 hold one job for an average of three months while 69 per cent of women aged 50 to 59 held the same job for less than twelve months. This data also shows that only is per cent of male employees enjoy job security of three years or more. Over all age ranges we find that 74 per cent of employees change jobs every six months, or have periods of unemployment between jobs. This is exacerbated by the increased role of employment agencies which offer short-term contracts, often on a day-to-day basis. This means that the workforce is fragmented and, due to the high turnover within the low-skilled job market, in a constant state of internal competition.

Of greatest concern, evidence also shows that there is a high level of poverty in Britain. A government survey showed that one-quarter of families spend between one and five years in poverty and that once in poverty it becomes increasingly likely that individuals will remain below the poverty line. The majority of those living in poverty are single-parent member of this class?". 
families with a female as head of the household. There is unlikely to be anyone in full-time, long-term employment in the household, despite being predominantly within the "prime" working age range. Thirty-two per cent have more than one child and overwhelmingly they have a low level of education..$^{2}$ These figures were summarized to infer "those lone parents who moved into work [...] stopped work again within a year, and half drifted in and out of unemployment for five years". 53 These people have little stake in the consumer society and find themselves largely excluded. Callinicos argues that this means they are unlikely to identify with procapitalist parties and so will reject the democratic process. ${ }^{54}$

\section{THE POST-INDUSTRIAL WORKING CLASS: AFTER BOILER SUITS AND PIT HELMETS}

There is, then, a working class as defined using traditional socioeconomic indicators: employees who have little or no power within the workplace, whose rights are under attack, who lack job security, who suffer from alienation and who find it difficult to move beyond certain types of employment. These are characteristics shared by the majority of those employed in the labour intensive industries throughout the first threequarters of the twentieth century. In the post-industrial economy, however, they are also significantly different. While once the domain of the male, it is now the female who is preponderant in labour-intensive, usually office-based, unskilled jobs. Equally, while once labour-intensive industries were the recruiting base for the trade unions, the reduction in union influence, and the end of the closed shop, has shown a steady decline in union membership. Across the manual industries only 29 per cent belong to a trade union; within the nonmanual occupations the membership is 30 per cent. The majority of call centres have an on-site union which most employees join. However, there is dissatisfaction with the ability of large unions, such as USDAW, to exert leverage over corporations. 55

52. HM Treasury, Persistent Poverty and Lifetime Inequality, CASEreport 5; HM Treasury, Occasional Paper, io (March 1999), pp. I42-143.

53. The Guardian (7 September 2000).

54. A. Callinicos, Against the Third Way (Cambridge, 200I), p. 5 I.

55. This was particularly the case at Empire Stores, Wakefield. The employees in the call centre were offered a wage increase of I. 5 per cent on 9 September 2000 ; this was rejected. The company refused to increase their offer. Although members discussed wildcat strikes, USDAW refused to back them and entered into negotiations with the management that saw meetings delayed and interest reduced. Also, due to the high turnover of staff, 35 per cent of employees who had originally voted "No" had left the company in the interim period. Those employed over the same period signed a contract stating they would not demand a wage increase within a I2-month period from the start of employment. The result was that when the management demanded a fresh ballot 22 September 200 I, by which time a fresh pay review should have been underway, members who could not vote against were in the majority. Though most did not attend the 
We should ask then what political issues motivate the post-industrial working class. The results of opinion polls can provide a picture of what issues are important to the electorate. Matching this with socioeconomic data can offer some indications of what determines current voting patterns in Britain. Crewe noted that, as unemployment increased under the Thatcher government, Labour should have been the natural beneficiary. Unemployment was of key concern to public opinion, as shown by MORI polls conducted between November 1982 and the General Election of June 1987. This data informs us that an average of 80 per cent of respondents placed unemployment as the highest priority. However, a combination of "apathy and fatalism" among the unemployed and those in insecure employment, coupled with a "profound scepticism that a Labour government would do much better in the short term", meant that Labour "lost the political argument". ${ }^{6}$

A similar case can be found on other issues of key public concern. In I979 reducing the power of the trade unions was an issue that had wide support. As Labour was the "organ of the trade unions", public opinion was clearly weighted against the party. However, the shockwaves of the "winter of discontent" 1978-1979, when the nation was brought to a virtual standstill due to industrial unrest, were short-lived. Unemployment became the key issue but as the overall level fell it was soon equalled by another Labour tenet: the National Health Service (NHS). The only reason this was kept from the agenda in the prelude to the 1992 General Election was because the electorate also prioritized the economy. While Labour retained the image of offering a high taxation and high spending policy; in contrast the Conservatives were seen as prudent and responsible. It was only the economic recession following Britain's forced exit from the European Exchange Rate Mechanism on i6 September 1992, subsequently dubbed "Black Wednesday", that shattered this perception. ${ }^{57}$ By 1996 the NHS became the public's top priority followed closely by education, Europe, law and order, unemployment, and the economy. Owing to the stability of the economy this issue received little attention and it was the aforementioned social-policy aspects that were prioritized by the Labour Party in the 1997 election campaign. These have remained key policy areas

meeting, those who voted against were a minority of the total employees so the pay increase of I.S per cent was passed without conflict. This information was gained informally through members of staff and union members. Empire Stores refused to pass any comment beyond the fact that a group of union members had held up the pay-review process which meant that no increase was awarded to employees for a year; this was publicized in the company newsletter to staff, undermining USDAW's position.

56. Crewe, "Labour Force Changes", p. 30.

57. H. Thompson, "Economic Policy under Thatcher and Major", in S. Ludlam and M.J. Smith, Contemporary British Conservatism (Basingstoke, I996), pp. I80-183. 
for the party and have been addressed while maintaining an image of economic competence.

The prioritization of collectivist concerns, particularly welfare and education, indicates that the politics of consumption are not as dominant now as they were ten years ago. However, polls also indicate that personal self-interest plays a significant role in voting. In June $200 \mathrm{I}$, mirroring the voting patterns of the election 4 days later, a national opinion poll found that 44 per cent believed they would be "better off" under Labour, only 23 per cent responded Conservative while indicatively 26 per cent, close to the average figure who did not vote in the election, said neither party. In the same poll, 50 per cent of respondents stated that "none of the parties really represents me". ${ }^{8}$ This shows that a significant section of the electorate were ambivalent about either of the major parties, sceptical regarding the importance of voting, and appeared to have rejected politics in favour of, as one non-voter argued, "getting on with my own life". 59 An ICM poll found that 45 per cent of respondents believed there was little difference between the Conservatives and Labour, while 57 per cent argued that the outcome of the election would not affect their daily lives. ${ }^{60}$ Though there are several factors which are argued to have led to a low turnout in $200 \mathrm{I},{ }^{6 \mathrm{I}}$ one aspect is the fact that a significant section within the British electorate no longer feel any strong partisan tie to any political party. Furthermore, and more importantly, this section saw the election result as a foregone conclusion and neither saw a need to vote or cared about the consequences.

\section{REALIGNMENT: MYTHS AND REALITIES}

Voter apathy may indicate a significant dealignment of the electorate in general and particularly of the traditional working-class Labour voter who, it seems, has almost disappeared from the political landscape. However, to substantiate this conclusion we must revisit our definition of the modern working class. This group is almost impossible to classify in socioeconomic, political, or cultural terms. They are from various backgrounds, have vastly differing political allegiances and represent a cross-section of race and gender. They are also far less likely to hold the same job, or work for the same company, for much more than twelve months. This means that there is extreme fragmentation, that working people can no longer be mobilized as a coherent group and that they have a

58. NOP poll published for The Sunday Times (3 June 200I).

59. Quoted in the Leicester Mercury (2 June 200I).

60. The Observer (3 June 200I).

61. See P. Whiteley et al., "Turnout”, Parliamentary Affairs, 54 (2001), pp. 775-788. 
very different view of community than their predecessors had during the ig6os.

Equally the working class are no longer a group in stasis. As Crewe observed, they enjoy: "greater social mobility [...] [and] internal migration". ${ }^{62}$ No longer will the sons of miners automatically be drawn to follow in their father's footsteps. The meritocracy of Thatcherism has liberated the post-industrial working-class generation: they can now break their own shackles and some have moved into the "professional classes". Furthermore, they are no longer tied to the community and have to be geographically mobile within Britain. This has led to a drift away from the industrial heartlands and the close-knit communities where Labour enjoyed a substantial majority. This encourages a break from filial partisanship and the adoption of the ideas of a new community. All this was predicted to dealign the supporters of the Labour Party unless the party developed new strategies that would enable them to retrieve working-class support as well as drawing support from other classes. ${ }^{63}$ This Labour seems to have done, updating many of the party's values in response to developments in both domestic and international politics and economics and in line with public opinion. ${ }^{64}$ To some extent this has led to re-alignment, but also for some to reject politics completely.

The 200I General Election saw Labour's majority retained. The Conservative Party made only two gains from Labour after attempting to run a populist electoral campaign. However, the real winner on 7 June $200 \mathrm{I}$ was argued to be apathy. There are various reasons for this: that the election was a foregone conclusion, that there was little significant difference between the main parties, and that there was a lack of identification with the parties. ${ }^{65}$ These factors, however, underline the fact that significant voter dealignment has taken place in the wake of deindustrialization. To some extent the two factors are linked: the breakdown of the working-class community that often worked and socialized together is one strong factor. More important though are the fragmentation of the working class in response to the post-Fordist production methods, and the growth of a large service sector. This has meant that the working class can no longer be mobilized as a coherent political actor, even within the regions where manufacturing is still the major source of employment. The significant alteration of the patterns of working means there are increased numbers of part-time workers, agency-employed

62. Crewe, "Labour Force Changes", p. 26.

63. Ibid., pp. 36-46. Interviews with former Conservative MPs and losing Conservative candidates at the $200 \mathrm{I}$ General Election draw similar conclusions about the Conservatives; this is also expressed in A. Seldon and P. Snowdon, A New Conservative Century (London, 200I). 64. J. Lees-Marshment and D. Lilleker, "Political Marketing and Traditional Values: 'Old Labour' for 'New Times'?”, Contemporary Politics, 7 (2001), pp. 205-2 I6.

65. Whiteley et al., "Turnout", pp. $775-788$. 
workers, short-term contractors, and a high turnover of staff throughout the unskilled and semiskilled employment sectors, all of which emphasize fragmentation. Finally, there is an increased level of understanding of politics and economics, a factor which is worth some consideration.

The increased awareness of the effects of inflation, deflation, and recession on the ordinary person's budget is clearly a product of the Thatcher years. As Prime Minister 1979-1990, Margaret Thatcher recognized the importance of making the individual understand the economics of government and enforced upon the public "New-Right" ideas. While the ideology was not accepted universally, the introduction of this level of knowledge has made the electorate think carefully when choosing who should manage the economy. Party election broadcasts throughout the I980s dwelt on the economic competence of both parties, with Labour suffering from having a weak record in economic policy. Black Wednesday, and the criticisms of the Major government by Labour leader John Smith and rising star Gordon Brown, restored public confidence in Labour. It is this confidence that now allows them to appear as the natural party of government; that is, until they make a mistake. Therefore, increasing insecurity and reliance on a strong economy means the electorate are increasingly forced to calculate which party will be the most economically competent. Overwhelmingly in both 1997 and 200I, Labour were able to assert this image. It appears then that the voter has realigned in favour of competence and stability, or using the terminology of the economist "utility and probability". Heath, Jowell, and Curtis (200I) argue that the electorate subconsciously "weights the utility of a given policy by the probability of its being implemented and sums this across the different policies" ${ }^{66}$ 'The voters' calculations reflect their social status: housing tenure, union membership etc., but are dominated more by an equation that calculates which party will improve their personal economic circumstances, not by any sense of class loyalty. Party ideology, name, or persona may have little significance to the individual with an insecure job, a mortgage, an overdraft, and a family to support.

Does this mean that there are no longer any such phenomena as political alignment and partisanship? Using MORI polls on party identification as a measure, it would appear that there is currently a strong sense of identification with, on average, 40 per cent of respondents I996-200I reporting that they thought of themselves as "Labour voters". However, looking at polls going back to 1990 we see that in that year 42 per cent claimed to be Labour supporters but that this figure waned to 32 per cent by the 1992 General Election. By March 1993 the figure increased steadily 
to 38 per cent and maintained this level until it steadily increased I996I 997 in time for the 1997 General Election. Troughs in support after I997 coincided with the refinery blockade in protest against tax on fuel and the outbreak of foot-and-mouth disease, though Labour's lowest point was 34 per cent while the Conservatives could not muster more than 27 per cent. The main beneficiary during these troughs was the "none of these" or "noparty" response which increased from an average of Io per cent from I993 to 1997 to I 6 per cent in May 200I. ${ }^{67}$ This tells us that party identification is highly volatile and more dependent upon perceptions of competence than loyalty or class-consciousness.

But what of the other sections of society: those who are unemployed, who retain class loyalties and a contiguous partisanship to the Left. It would seem that some have rejected the Labour model and have elected to support other left-wing political groupings. Both the Socialist Alliance, the major left-wing electoral alternative to Labour, and the Socialist Worker's Party (SWP), a Marxist revolutionary party, claim to enjoy a substantial level of working-class support. The SWP has been prominent in many anticapitalist demonstrations as well as supporting the pay claims of various public-sector workers. This has gained them some trade-union sponsorship. However, SWP activists are predominantly intellectuals, often within the education sector, while their volunteers tend to be unemployed. Furthermore, the SWP refuse to take part in elections and therefore their support is difficult to measure. ${ }^{68}$

Electorally, the Left appears to be in disarray. Dave Nellist, former Labour Member of Parliament, and local councillor representing the Socialist Alliance in Coventry, gained only 2,638 votes, though this was 7 per cent of those who voted. Elsewhere, left-wing luminary and former leader of the National Union of Mineworkers (NUM), Arthur Scargill, gained only 9I 2 votes, 2.4 per cent of the turnout, in the former NUM heartland of Hartlepool, and the average result for a Socialist candidate was $\mathrm{I}, 500$ votes or 5 per cent of the turnout. We could conclude that a 5 per cent swing to non-Labour left-wing political parties is significant, and that many of those who did not vote may also have voted for these parties but refused to do so in the belief that they had little chance of winning. However, there is little evidence to substantiate these claims. In many constituencies the Left appeared extremely fragmented, with Socialist Alliance, Communist Party, Socialist Alternative, and Socialist Labour

67. Archives of MORI polls can be obtained from the Nuffield College, Oxford website: http:// www.nuff.ox.ac.uk/library/statistics.shtml

68. Two interviews with SWP workers were carried out: they gave an interesting picture of their membership but were unable to provide any figures. Their annual event, the Marxism Conference, held at the University of London campus, attracts around 7,000-8,000 delegates from a cross-section of society. In a survey of socioeconomic status, carried out at the $200 \mathrm{r}$ event, students were massively over-represented however. 
candidates fighting each other for a very small proportion of the electorate. In Aberavon, the Socialist Alliance candidate found himself last, beaten by a $\mathrm{Mr}$ Tutton standing as a "rate payer" and the "joke" candidate representing the "New Millennium Bean" party. Even in Scotland, where the Scottish Socialist Party is established and nationally known, the picture is identical. Only right-wing neofascist National Front and British National Party (BNP) candidates made advances against the stranglehold of the major three parties. But the BNP gains of 16 per cent of the turnout in two constituencies in Oldham, in the heart of the former industrial area of Greater Manchester, was a reflection of long-standing conflicts between the White and Asian-English communities which had become inflamed in the months prior to the 200 I election.

\section{CONCLUSIONS}

Class partisanship has never been a clear-cut, definable phenomena in Britain. Voters make their choices based upon a range of factors, but personal interest has often been a more serious consideration than classconsciousness. As de-industrialization altered the shape of British society, Labour appeared initially unable to offer a credible response and personal economic circumstances, and the perception that the Conservatives offered the working class a better standard of living, predominated. Thus, filial ties to the Labour Party were weakened. Since 1997, it appears that the majority of the working class do vote Labour, but respondents to opinion polls seldom argue that they do so because they are obliged to out of a sense of class loyalty. It is arguably the case that without surveying every individual voter who holds working-class credentials it is impossible to quantify how the working class votes, or whether any partisan identity remains among those who can be classified as working-class. This is perhaps the central conclusion of this paper. The post-industrial working class is fragmented: it lacks a clear political or class identity and is dominated by self-interest rather than class-consciousness. Therefore, each individual will have a personal reason for voting and class-consciousness holds little significance. As Wright argued "people" have replaced "class" as the integer of politics, and concerns can be identified more with race and gender than by socioeconomic classifications. Though some group activism is engaged in, this represents postmodern social movements: voting is influenced more by personal aspirations and beliefs than group identity. But how far is this different to the working class of previous decades?

Various periods within the nineteenth and twentieth centuries witnessed the working-class acting in unison, a feature of the centralized production methods of mining and the steel industry. However, despite this image of unity and class solidarity, the members often fought for personal gains. 
Working-class solidarity may have been the battle-cry of the strike leader but many individual workers sought pay increases and job security on a personal basis as well as in the name of the community. The inequalities that led classes, or sections of a class, to mobilize still exist; it is the mobilization structures and the loci of working-class activities that have been eroded. This has not occurred, as Goldthorpe argued, because "class inequalities of condition and opportunity progressively diminish", ${ }^{69}$ but because the inequalities in the modern world are not faced by any one single class. They cut across classes, and are now the terrain of groups who can be more accurately defined in terms of race, gender, age, education, skills, and experience. These factors also shape the individual's consciousness to a far greater extent than notions of social status. Using socioeconomic stratification measures, a large working class still exists. They work in alienating conditions and face obstacles in moving above that socioeconomic status, though this group can no longer be characterized as white male manual workers who think of themselves as working-class. The post-Fordist, post-industrial working class is a far more disparate animal.

The most marked changes are: the reduction in the power of the working class and the decline in class identity; a change in the composition of those employed in the lowest paid, labour-intensive occupational sectors; the fragmentation of trade-union membership; and a degree of acquiescence or political apathy among all but a militant minority. All of this is reinforced by increased affluence in a consumerist society. The culture of acquisition distracts the worker from the alienating conditions of production by providing an end product for their labours: the car, television, DVD player etc. have become of greater symbolic value than class unity or party politics. Labour's failure to provide economic benefits led those classified as affluent workers to vote Conservative in increasing numbers in order to protect their standard of living; thus, Labour have had to become a party of the centre ground, representing the aspirant while claiming to also protect the deprived.

It is those who we can characterize as the "deprived", or in New-Labour terms the "socially excluded", that represent the most interesting section of the British electorate. This section of society feels keenly the need for political representation and workplace activism. However, in reality these individuals have largely become marginalized and consequently are apathetic to the political process. In many ways it seems these people share a collective memory of mass unemployment and its effects upon local communities. As Bagguley argues "in some localities there were powerful organizational and cultural resources for the unemployed to draw upon". But as the larger trade unions had their powers curbed and

69. P. Mair, S. Lipset, M. Hout, and J. Goldthorpe, "Critical Commentary: Four Perspectives on the End of Class Politics”, in Evans, The End of Class, p. 320. 
saw their membership decline, while communist parties and workers' cooperative societies became unable to sustain themselves financially, such institutions disappeared. This resulted in "a shift in political response amongst the unemployed from protest to acquiescence". ${ }^{\circ}$ The left-wing organizations failed to attract the unemployed or those in unstable employment because they lacked credibility and could muster no more than 2,638 votes at elections; thus perhaps socialism is dead after all. Apathy appears to have been the real beneficiary of dealigned workingclass voters, a factor that could indicate complete dealignment without any form of realignment. Calls for tactical voting, ${ }^{71}$ the similarity between the major parties, and the growth of personality politics have all been highlighted as reasons why the electorate was "turned off" in $200 \mathrm{I}$. However, the lack of credible working-class representation, the position put forward by the Socialist Alliance, could also be a legitimate hypothesis. Among the respondents who claimed all the parties were similar were a subgroup who argued that none spoke "their language", that all the parties "represented business not people", and that "balancing the budget meant more than doing what the people wanted". This is disaffection and dealignment of a serious nature. These respondents not only did not vote for their traditional party but rejected the democratic process completely. Some did opt to vote for marginal parties: in the most obvious case it was the neofascist British National Party that benefited. Others it seems stayed at home and watched the election as a foregone conclusion. As one worker put it, "it didn't matter how you voted, you knew a bloody politician would get in".

70. P. Bagguley, From Protest to Acquiescence: Political Movements of the Unemployed (London, I99I), p. 203.

7I. The tactic whereby Labour voters will vote Liberal Democrat if the combined Labour and Liberal Democrat vote would defeat the incumbent Conservative was first used in I 997 when Liberal Democrats urged their supporters to vote Labour in order to remove the Conservatives from office. In $200 \mathrm{I}$ tactical voting was mainly promoted by Liberal Democrats in marginal constituencies where the anti-Conservative vote was divided between Labour and the Liberal Democrats, but was also suggested, more surreptitiously, by Labour canvassers in key marginal constituencies, though the tactic was condemned by the Labour leadership. 